\title{
Euthanasia - A Right of the Human Being or a Crime against Humanity?
}

Andrada Nour ${ }^{*}$

Lecturer, Faculty of Law, Hyperion University, Bucharest, Romania

DOI: $10.36348 /$ sijlcj.2020.v03i05.001

| Received: 21.04.2020 | Accepted: 30.04.2020 | Published: 07.05.2020

*Corresponding author: Andrada Nour

\section{Abstract}

Although subject to some of the most important international documents is the fundamental rights and freedoms of man, however, in today's society the man has lost sense of the value and of the dignity of the person and of the sacred human life. Throughout time, man has had a varying attitude toward his own life, just as society's attitude towards its members lives had been variable. When we speak of euthanasia we are talking about human life. This way we come to ask ourselves on the value of life, its foundation and its principle. Although all European States, as well as numerous other countries worldwide have dropped the death penalty and, although it advocated for the abolition of the death penalty throughout the world, human euthanasia or medical assisted suicide is tolerated or legalized. Moreover, in the states where human euthanasia has been decriminalized "for humanitarian reasons", major protests are held against the euthanasia of animals. We live in an age of paradoxes... We live in a time when it is trying to inoculate that everything is done in order that mankind lead a life as easy ... If life has its roughness, then we cannot not ask ourselves why and for what we endure? There is a moment in which to terminate life support aimed to make it to become an act morally? How could it be described such a moment?

Keywords: Euthanasia, medical assisted suicide, death penalty, legalization, decriminalization, incrimination.

Copyright @ 2020: This is an open-access article distributed under the terms of the Creative Commons Attribution license which permits unrestricted use, distribution, and reproduction in any medium for non-commercial use (NonCommercial, or CC-BY-NC) provided the original author and source are credited.

\section{INTRODUCTION}

\section{Considerations on the legal situation of euthanasia in the world}

It is well known that euthanasia has been practiced in different forms (either "voluntary" or even "imposed" in the cases of incurable patients and with malformations), since ancient times, the first mention of human euthanasia dating back to Antiquity.

Of course, and then as nowadays, there were polemics about euthanasia. Pythagoras, Cicero and Hippocrates also opposed this practice. Moreover, although he admitted passive euthanasia, that is leaving the patient without hope, he forbade the active one, Hippocrates expressly mentioning in his famous oath that: "I will not be determined by the word of anybody to procure a poison or to get me give consent to this.

Without being an invention of our time, euthanasia has materialized as a "flight of suffering" for those affected by incurable diseases and plagued by atrocious pain. It is undeniable that the human being has always expressed in such cases the desire to die, to be freed from death by suffering.
Since the 1970s, a real campaign for euthanasia has spread worldwide, understood either as an action or as an omission, causing the interruption of the life of a seriously ill patients or even of the unborn child with malformations, on the grounds that the patient must be exempted from suffering considered unnecessary. There are a number of pro-euthanasia movements, supported by companies such as the Society for Voluntary Euthanasia, in the Netherlands (1973) or other similar societies in Germany and Japan (in 1976); in 1980, the Word Federation of Right-to-Die Societies was created, formed in Oxford, England by 27 groups from 18 nations. In 1984, the Supreme Court of the Netherlands approves (under certain conditions) the practice of euthanasia. Seven years later, in 1991, the US Congress approves the Patient Self-Determination Act, which requires hospitals to comply with "living wills" and in 1992, the British Medical Association expresses its agreement regarding "living wills" (the legal document which allows each individual to choose in writing how he wants to be treated when he will no longer be able to give his consent, if his health conditions are irreversible). 
Australia was the first country in the world that decriminalized euthanasia and medical-assisted suicide by a doctor or computer by a law approved in the Territory on Northern Australia in July 1996, keeping it in force for only a few months, until March 25, 1997, when it was repealed by the Australian Federal Parliament. During that time, four cases of euthanasia or assisted suicide have been reported.

In 1998, the Government of China authorizes the suppression of terminally ill patients and later in Europe, the Netherlands (April 10, 2001) and Belgium (September 23, 2002) each approve a law by which euthanasia is virtually removed from criminal law.

Although the Netherlands criminalizes human euthanasia as an offence, it still admits an exception, in the case of patients whose suffering is unbearable and without any prospect of improvement. Therefore, if the doctor who ends the life on request or helps the suicide of a patient, meets the legal criteria for care and communicates the death of non-natural causes to the appropriate regional euthanasia review committees, he will not be held criminal liable.

Thus, the doctor who meets a request for euthanasia will draw up a report and submit it to a review committee. Only if the committee decides, based on the report, that the doctor has failed to meet the legal criteria for care, will be informed the Public Service Prosecutor's Office and the Regional Health Inspectorate, institutions that will decide whether or not to prosecute the doctor.

The Dutch Government considers that the decriminalization of euthanasia or medically assisted suicide does not contravene the main international instruments for the protection of human rights (Article 6 of UN International Covenant on Civil and Article 2 of Political Rights and the European Convention on Human Rights (ECHR)), motivating that legal provision it is based on respect for life and that international documents, although they prohibit the right to take the life of an individual against his will (excepting special situations, such as sentencing to death) trying to ensure the protection of the right to life [i], are not intended to perpetuate an unbearable suffering if there is no prospect of improvement. The Netherlands respects the human rights provided in all the international documents, considering that the voluntary human euthanasia of a patient does not constitute the deliberate deprivation of the right to life, in the sense of the international provisions referred to above, considering that these international conventions are not of strict interpretation. Dutch legislation on euthanasia is based on respect for life, which is why the Netherlands does not prohibit its citizens from deciding for themselves or for their lives [ii].
Voluntary euthanasia is legal in India [iii]. On March 7, 2011, the Supreme Court of India legalized passive euthanasia, by suppressing the life of patients in permanent vegetative condition [iv], but the forms of active euthanasia, including the administration of lethal compounds, are illegal [v].

Following the tradition of national law (article 469 of the Romanian Criminal Code of 1936), as well as the criminal policy of the European states in this matter (article 216 German Penal Code, article 77 Austrian Penal Code, article 143 paragraph (4) Spanish Penal Code, article 134 Portuguese Penal Code, article 114 Switzerland Penal Code, article 235 in Norway Penal Code), in Romania, by entering into force of the current Criminal Code, it is incriminated in the article 190, as an attenuated form of the crime of murder, the murder committed at the explicit, serious, conscious and repeated request of the victim who suffered from an incurable disease or a serious infirmity medical certified, causing permanent and difficult to bear sufferings.

However, at the opposite end, there were released a number of documents such as the Declaration on euthanasia of the Congregation for the Doctrine of the Faith (May 5, 1980) or the Declaration on the final phase of the disease of the World Medical Association (1983), which strongly condemned the practice of euthanasia and which also confirms the need to provide appropriate medical care to the suffering people.

The Haas case against Switzerland is also well known, where the European Court of Human Rights in Strasbourg rejects the claimant's request, confirming once again that it is inadmissible to invoke the European Convention on Human Rights in order to legalize a possible right to euthanasia or medical assisted suicide. Claimant Ernst G. Haas, suffering from severe mental disorders, wanted to commit suicide by using a substance, released only on prescription, in accordance with Swiss law. Failing to comply with the provisions of Swiss law, Haas tried to obtain a derogation, based on his request under Article 8 of the European Convention on Human Rights, which he motivated by violating the right to privacy.

From the judicial practice of the member states of the Council of Europe regarding the authorization of the definitive interruption of the medical treatments that aim only at artificially prolonging the life of the patient, we observe that there is no consensus in this respect, a situation due to the legislation, which either prohibits the cessation of the treatments, or does not contain provisions relating to the issue in question. Most of the states authorize this practice, but conditionally, there are provisions in legislation or other documents, such as medical deontology codes. The case of Italy is somewhat different, in the sense that although legal imperatives do not exist regarding the definitive 
interruption of the medical treatments whose sole purpose is the artificially extension of life, nevertheless the jurisprudence recognizes this possibility.

We can speak of a consensus at European level regarding the essential role played by the patient's desire or will in the sense of interrupting treatment in such cases, by virtue of the right to respect for private life. In this context, procedures have been set up at the state level to allow the patient to express his consent, as well as to verify the existence of the consent. In the states where the legislation allows the definitive interruption of the treatment, the patients have the possibility to formulate advance directives, and in those where there are no legal provisions of the same nature, the decision can be made by the treating doctor, the relatives or the spouse of the patient, the legal representative or the judge. At the same time, the patient is required to be dying or the disease he suffers from is incurable, treatment unnecessary, its continuation not being anymore in the best interest of the patient. We express the opinion that regarding the authorization of the medical assisted suicide and euthanasia, whether it is about the active form or the active one, there is no consensus among the other states of the world, not only at the level of the member states of the Council of Europe.

\section{RESEARCH METHODS}

The present work constitutes a normative legal research, based on materials of legal nature of primary, secondary and tertiary type. The research represents an analytical, conceptual and statutory approach to a complex issue, namely human euthanasia, much debated at international level. The paper refers to existing legal provisions at the level of the national legislation of the states, as well as to international provisions. The data and information used in this study were collected from literary sources, scientific legal papers, national and international legislation closely related to the researched issue. The primary and secondary legal materials were analyzed by correlation with the legal and medical principles of reference in the matter.

\section{RESULTS AND DISCUSSION Pro euthanasia arguments}

The problem of euthanasia of the patients in the terminal stage of a disease upon request, as well as the tendency to legalize this phenomenon are strongly supported by social communication tools, in order to awaken favorable beliefs. Based on many factors with a rational basis, in support of this cause, appeal is also made to feeling and emotionality. In a world where humanism gains an atheistic vision, contemporary human society seems overwhelmed by a profound sense of fear of death and seeks to defend itself. Here is the meaning of euthanasia, a pain-free death that allows the individual to die with dignity, sparing the suffering and others. Sometimes the mercy and compassion of those close to the patient, helpless in the face of his torment, causes the patient to request euthanasia. Sometimes, on the contrary, abandonment of the patient by the family and isolation in a hospital unit have the effect of formulating the request for euthanasia.

Utilitarians support the phenomenon by virtue of the principle of quality of life, considering that euthanizing a patient lacking the state of consciousness and dependent on the medical equipment that maintains their vital functions is not crime, but a gesture based on feelings of pity.

The willingness of the patient to die, pathological (due to depression or inability to decide, to be balanced) or even healthy (although some argue that there are only pathological cases), is a will determined by fear of pain; by unbearable pain; of human dignity; despair, frustration or meaninglessness of life or hope for healing; from the feeling of worthlessness, loneliness or rebellion against medical technologies, isolation, disease. Subsequently, the patient justifies these motivations, using arguments such as responsibility to oneself; denial of suffering; the compassion, altruism, charity towards the family or society, the freedom and autonomy of the human person who would give him the right to decide.

Proponents of euthanasia are based on the principle of freedom and autonomy or selfdetermination of the patient, according to which each individual has the right to decide what concerns him, without any external interference, being master of his own body. Starting from this premise, the doctor could no longer deny the death of the person requesting it, and if in the past his role was limited to the patient's duty of care, presently this role was extended and to help the patient to die, contrary to the deontology and the oath taken at entering the profession. Thus, the patient will have the confidence that the doctor will satisfy his wish, respecting his "right" to choose death. Although the primary duty of physicians is to preserve life, they also have the obligation to do everything they can to respect their patients the right to die with dignity. The doctor becomes responsible for alleviating the patient's suffering, having the obligation to stop administering medical treatments unnecessarily if all treatment options have been exhausted.

Another argument in favor of this phenomenon could be the fact that certain categories of people can be eliminated from society, such as the quite large elderly population, which is growing continuously.

Also, euthanasia seems to be practiced extensively in secret, based on arbitrary decisions and even under obscure conditions. Supporters of this phenomenon believe that in the event of legislation, although the abuses will not disappear, their number 
will certainly be much lower, and decriminalization of euthanasia and medical-assisted suicide could contribute to a better supervision and even to the prevention of reducing the incidence of such requests from the patients.

\section{Arguments against euthanasia}

As we have seen before, the main arguments in favor of euthanasia are based in particular on the meaninglessness of the suffering and on the freedom to choose death, that is, on personal autonomy. In the Christian context, however, the argument of suppressing life because of its quality is irrelevant, tackling these issues with other starting points: suffering has a meaning and man is not completely autonomous.

However, we consider unacceptable that the principle of autonomy justifies the suppression of one's own life or that of another person, starting from the idea that the responsible individual has the freedom to be, not that of not to be. Christian doctrine supports this view, pointing out that man cannot choose the end, as long as he has not had the freedom to choose his birth, and that freedom means responsibility before God.

According to the Christian doctrine, no one has the right to suppress the life of man or to kill himself, even if it is near the end and in extreme suffering. From Christian point of view, euthanasia is tantamount to murder or suicide.

The church considers euthanasia a criminal act by its nature, morally unacceptable, a position explained in the Catechism of the Catholic Church since 1992 [vi]. In Evangelium vitae (1995), Pope John Paul II consecrated an entire chapter to euthanasia, stating that "If we value life only to the extent that it brings pleasure and well-being to us, death taken by absurdity if it often interrupts the life still opened to a rich future of interesting experiences to make, on the contrary it becomes a liberation demanded while the existence is considered as meaningless since it is thrown into pain and inexorably destined for the increasingly acute sufferings" [vii].

Euthanasia is also forbidden in Islam [viii], being unacceptable, no matter would be the reason, suicide or any action used to help someone to suppress his life, according to two principle: life is sacred [ix] and only Allah decides how long people will live $[\mathrm{x}]$.

Euthanasia is dangerous from several points of view. Its justification opens an easy way to exterminate the "unspeakable", those with abilities different from the "standard". If medical treatments become expensive, relatives of some patients may prefer euthanasia instead of financial sacrifices. Last but not least, its acceptance would mean lowering the quality of palliative treatments and diminishing doctors' efforts to save human lives. Given that the law must protect the interests of society as a whole and against abuse, we must not ignore the fact that legalizing the suppression of the individual can cause serious wrongdoing [xi].

Nor should we ignore the fact that behind the decriminalization and legalization of euthanasia and medically assisted suicide can be hidden and aspects related to considerable public expenditure, considered unnecessary in the face of prolongation of diseases and whose coverage is difficult to achieve. Even if the prolongation of the life of a patient imposes a burden on the society in which he lives, however, the state cannot deprive its citizens of their dignity and the rights they have.

Moreover, from voluntary euthanasia can irreversibly reach involuntary euthanasia or other abuses; also, voluntary euthanasia can be a mask for involuntary or even homicide.

Essentially, by virtue of deontology, the role of the physician is to sustain life and to treat pain, not to procure death. As long as a doctor practices euthanasia, he can no longer be trusted, and the patient must trust his doctor. The basic principle of the medical profession is that the doctor "help and heal, do no harm, do not destroy or kill" [xii]. "The law of the doctor can therefore never allow that the doctor or that the patient to practice direct euthanasia, and the doctor can never practice it neither on himself nor on others" [xiii], not even when he was asked to do it.

Human life is intangible, and public authorities cannot violate this principle by elaborating an order that involves the elimination of a patient with disabilities or who is in the terminal stage of a disease. In such a situation, both the one who gives such an order and the one who executes it would be guilty of the crime against humanity [xiv].

Another argument is that exceptions are not a good basis for legalization, and euthanasia, although practiced legally in different countries, is an exception and must remain so.

The protection of life is aimed at all persons, be they healthy, sick and dying, not being allowed to suppress the life of anyone, no matter how hard the suffering they endure, no matter how long they have to live, this is valid and in case the patient gives his consent $[\mathrm{xv}]$. Therefore, euthanasia is not allowed, that is, the murder committed under the impulse of a feeling of mercy to end the permanent and difficult to bear suffering caused by an incurable disease, after which death is inevitable [xvi].

Euthanasia is a crime that no human law can decriminalize. Laws of this nature do not create any obligation for conscience, but they entail a serious and 
precise obligation to oppose by conscientious objection [xvii]. As they oppose both the good of the individual and the common good, the laws that authorize such practices are totally void of authentic legal validity [xviii].

\section{CONCLUSIONS}

The paper aimed to draw general lines to act at personal and community level in the social, medical, political, economic and cultural fields in order to promote good and remove evil, thus promoting the true image of the priceless value of life.

Euthanasia and medically assisted suicide are concrete and current problems, and the reactions and attitudes they generate make these issues a controversial topic worldwide. As we have seen in these few lines of this paper, opinions on euthanasia are divided.

Euthanasia appears as an effect of the consumerism and utilitarianism of today's human society and, in my opinion, the attempt to instrumentalize life should be considered unacceptable, as the very essence of life would be lost. Undoubtedly, the man of contemporary society is living a great drama. On the one hand, he does not enjoy total freedom, and on the other hand, being under the domination of selfish and self-centered conceptions, the contemporary man gets to make incorrect decisions, ignoring certain aspects of the problem. Against this background, only logical and human in appearance, the temptation of euthanasia will get stronger and stronger. Analyzed in depth, however, it can only be absurd and inhuman. Once legalized euthanasia, the sense of justice is lost and the mutual trust, the foundation of any true relationship between persons, is undermined. Reduced to the essence, euthanasia is a cosmetic crime.

We consider that, the human euthanasia incriminated as an attenuated form of the crime of murder alters on the one hand the doctor-patient relationship, and on the other, it represents the first step towards the full legalization of euthanasia and, as it happened in some countries, through legalization, these practices have come to be seen as true forms of treatment, never being able to control them.

Although similar provisions exist in several states of the world, in our opinion, in Romania, the regulation of the crime of murder at the request of the victim did not represent a real emergency requiring regulation, especially because, as we have already seen in some states, from euthanasia and assisted suicide regulated only for serious cases, it has been reached to the murder at the request of the victim.

\section{REFERENCES}

1. Article 2 of the European Convention on Human Rights (ECHR).

2. Nour, A. (2013). Euthanasia between incrimination and decriminalization. In Volume of the International Conference on Law, Studies, and International Relations with the theme The legislative policy between European, national and international regulation. New perspectives of the law (pp. 346-354). Bucharest, Romania: Hamangiu Publishing House.

3. "India joins select nations in legalizing "passive euthanasia"". Chennai, India: The Hindu. 7 March 2011. Retrieved 8 March 2011.

4. "Euthanasia: The Approach of the Courts in Israel and the Application of Jewish Law Principles". Jewish Virtual Library; Venkatesan, J. (7 March 2011). "Supreme Court disallows friend's plea for mercy killing of vegetative Aruna". Chennai, India: The Hindu. Retrieved 7 March 2011.

5. Magnier, Mark (8 March 2011). "India's Supreme Court lays out euthanasia guidelines". LA Times. Retrieved 8 March 2011.

6. Catechism of the Catholic Church, Roman Catholic Archdiocese (1993). Bucharest. § 2276 to 2279.

7. Jean-Michel Rudent in http://www.generationjpii.org/article180.html(10 ian 2005).

8. "And do not kill yourselves. Surely, Allah is most merciful to you." Qur'an 4.29.

9. "And do not kill anyone which Allah has forbidden, except for a just cause". Qur'an 17.33.

10. "And no person can ever die except by Allah's leave and at an appointed term". Qur'an 3.145.

11. http://www.apostolia.eu/articol_289/cuvantdespre-eutanasie.html

12. PIO XII, „Alla decimasesta sessione dell'ufficio internazionale di documentazione di medicina militare" (19.10.1953) in Discorsi ai medici, 302.

13. PIO XII, „Radiomessaggio al settimo congresso internazionale dei medici cattolici” (11.09.1956) in Discorsi ai medici, 514.

14. Gino CONCETTI, L'eutanasia. Aspetti giuridici, teologici, morali, AVE, Roma 1987, 25-26.

15. Boroi, A. (2008). Criminal law. The special part (2nd ed.). Bucharest, Romania: $\mathrm{CH}$ Beck Publishing House.

16. Neculau, C. (2011). Consent of the injured person - justifying cause in the regulations of the new Criminal Code. Law review, 2011/4, p.89. Bucharest, Romania.

17. Ioan Paul al II-lea, Evangelium Vitae, Ed. Piemme, Casale Monferrato, 1995, no. 65-67, 128133.

18. Ioan Paul al II-lea, Evangelium Vitae, Ed. Piemme, Casale Monferrato, 1995, no. 65-67, 128133. 